Погребняк А.Ю.

Національний технічний університет Украӥни «КПІ»

\title{
ПРОЦЕДУРА ВИБОРУ МЕХАНІЗМУ АНТИКРИЗОВОГО УПРАВЛІННЯ НА ПІДПРИЕМСТВАХ МАШИНОБУДУВАННЯ
}

\section{ПРОЦЕДУРА ВЫБОРА МЕХАНИЗМА АНТИКРИЗИСНОГО УПРАВЛЕНИЯ НА ПРЕДПРИЯТИЯХ МАШИНОСТРОЕНИЯ}

\author{
PROCEDURE OF CHOICE MECHANISM CRISIS MANAGEMENT IN \\ MECHANICAL ENGINEERING ENTERPRISES
}

У статті досліджено прочедуру вибору механізму антикризового управління на підприємствах машинобудування як основу для накопичення антикризового потенціалу. Автором визначено, щуо основою вибору механізму антикризового управління $\epsilon$ діагностика кризового стану. Оиінювання ефективності наявного механізму запропоновано здійснювати шляхом розрахунку інтегрального показника ефективності механізму антикризового управління за показниками збалансованої системи. 3 метою вибору інструментів антикризового управління, адекватних стану кризових явищ на підприємствах запропоновано інтерпретацію меж інтегрального показника ефективності механізму антикризового управління. Застосування математичного апарату та запропонованої етапності виведення підприємства із стану кризи дають можливість розрахувати прогнозні значення інтегрального показника ефективності механізму антикризового управління, надати рекомендащії щзодо інструментів механізму антикризового управління та виявити накопичений антикризовий потенціал.

Ключові слова: криза, підприємство, механізм антикризовового управління, інтегральний показник ефективності механізму антикризового управління, антикризовий потенціал.

В статье исследовано прочедуру выбора механизма антикризисного управления на предприятиях машиностроения в качестве основы для накопления антикризисного потенциала. Автором определено, что основой выбора механизма антикризисного управления является диагностика кризисного состояния. Оиенка эффективности существующего механизма предложено осуществлять путем расчета интегрального показателя эффрективности механизма антикризисного управления по показателям сбалансированной системы. С иелью выбора инструментов антикризисного управления, адекватных состояния кризисных явлений на предприятиях предложено интерпретацию грании интегрального показателя эффективности механизма антикризисного управления. Применение математического аппарата и предложенной последовательности вывода предприятия из состояния кризиса дают возможность рассчитать прогнозные значения интегрального показателя эффективности механизма антикризисного управления, дать рекомендации по инструментов механизма антикризисного управления и вылвить накопленный антикризисный потенциал.

Ключевые слова: кризис, предприятие, механизм антикризовового управления, интегральный показатель эффективности механизма антикризисного управления, антикризисный потенциал.

In the article the procedure of choice crisis management mechanism in the mechanical engineering enterprises as the basis for the accumulation crisis potential. The author defines that the basis of selection mechanism of crisis management is to diagnose the crisis. Evaluation of the effectiveness of existing mechanisms proposed exercise by calculating the integral index of 
the effectiveness of the crisis management system for balanced scorecard. Proposed interpretation of the integral index limits the effectiveness of the crisis management for choice of the instruments of crisis management, adequate state of crisis at the enterprises. The use of mathematical tools and phasing of the proposed withdrawal of the company from a state of crisis, make it possible to calculate the predicted values of the integral index of the effectiveness of the crisis management, provide advice on crisis management tools and machinery gained detect crisis potential.

Keywords: crisis, enterprise mechanism of crisis management, integrated performance indicator mechanism of crisis management, crisis potential.

Вступ. В умовах світової фінансової кризи та системної кризи національного господарства для підприємств машинобудування характерним $\epsilon$ різке та постійне скорочення основних показників фінансово-господарської діяльності, що свідчить про внутрішні кризові процеси. У цих умовах одним 3 першочергових завдань для підприємств машинобудування є збереження та раціональне використання наявних і потенційних ресурсів, а також вчасне формування та дієве застосування механізму антикризового управління. Він здатен забезпечити накопичення антикризового потенціалу i можливості адаптації підприємств машинобудування як до екзогенних, так і ендогенних факторів середовища, мінімізуючи ризики поглиблення кризових явищ.

Питання сутності антикризового управління, особливостей його реалізації у практичній діяльності підприємств досліджуються у працях іноземних вчених: С.Беляєва, А.Грязнова, А.Ковальова, Е.Короткова, В.Кошкіна, Е.Мінаєва, В.Панагушина, Л.Планкетта, Н.Родіонової, А.Томпсона, В.Василенко, А.Колос, О.Копилюк, О.Кузьміна, , П. Круш, Л.Лігоненко, В.Мартиненка, Н. Рекової, Н.Скворцова, Н.Сейсебаєвої, О.Терещенка, О.Тридіда та ін.

Віддаючи належне значущості наукових надбань вітчизняних та закордонних вчених, слід зазначити, що у більшості наукових праць, присвячених даному питанню, увага приділяється теоретичним положенням загального характеру щодо антикризового управління. В той же час питання, пов'язані 3 проблемами прикладного використання інструментарію антикризового управління, його взаємозв'язку з кризовими явищами, а також формування механізму антикризового управління, оцінювання його ефективності як основи вибору раціональних заходів, які сприятимуть виходу підприємств 3 кризи та пї недопущення, залишаються найменш висвітленими.

Постановка завдання. Метою статті є узагальнення наукових підходів до процедури вибору механізму антикризового управління на підприємствах машинобудування.

Методологія. Для досягнення поставленої мети були використані загальнонаукові та спеціальні методи наукового пізнання. Зокрема, такі методи як: діалектичний, комплексного системного підходу, наукової абстракції, аналізу і синтезу використано при вивченні та узагальненні теоретико-методичних засад антикризового управління підприємствами, механізму антикризового управління; методи екстраполяції, експертних 
оцінок - при виборі механізму антикризового управління; таксонометричний метод, метод гармонійних ваг - для пошуку значень інтегрального показника ефективності механізму антикризового управління на підприємствах машинобудування.

Теоретичною базою дослідження стали наукові праці вітчизняних та зарубіжних учених щодо застосування механізму антикризового управління на підприємствах.

Результати дослідження. В умовах кризових явищ перед підприємством стоїть завдання розробляти та запроваджувати антикризові стратегії і відповідні механізми, що дозволять швидкими темпами та 3 мінімальними витратами подолати i у подальшому не допускати їх розгортання. При цьому має бути враховано глибину кризи. Визначальна стратегія може бути спрямована на забезпечення стійкого зростання i розвитку за рахунок стабілізаційного або запобіжного механізму. Проте якщо підприємство знаходиться в стані кризи боргової платоспроможності (на межі банкрутства), необхідно застосовувати антикризові заходи в рамках стратегій радикального механізму.

Як свідчать результати аналізу наукової літератури [5-7], вибір механізму антикризового управління на підприємствах машинобудування доцільно здійснювати з урахуванням послідовності взаємопов'язаних етапів виведення підприємства зі стану кризи (рис. 1).

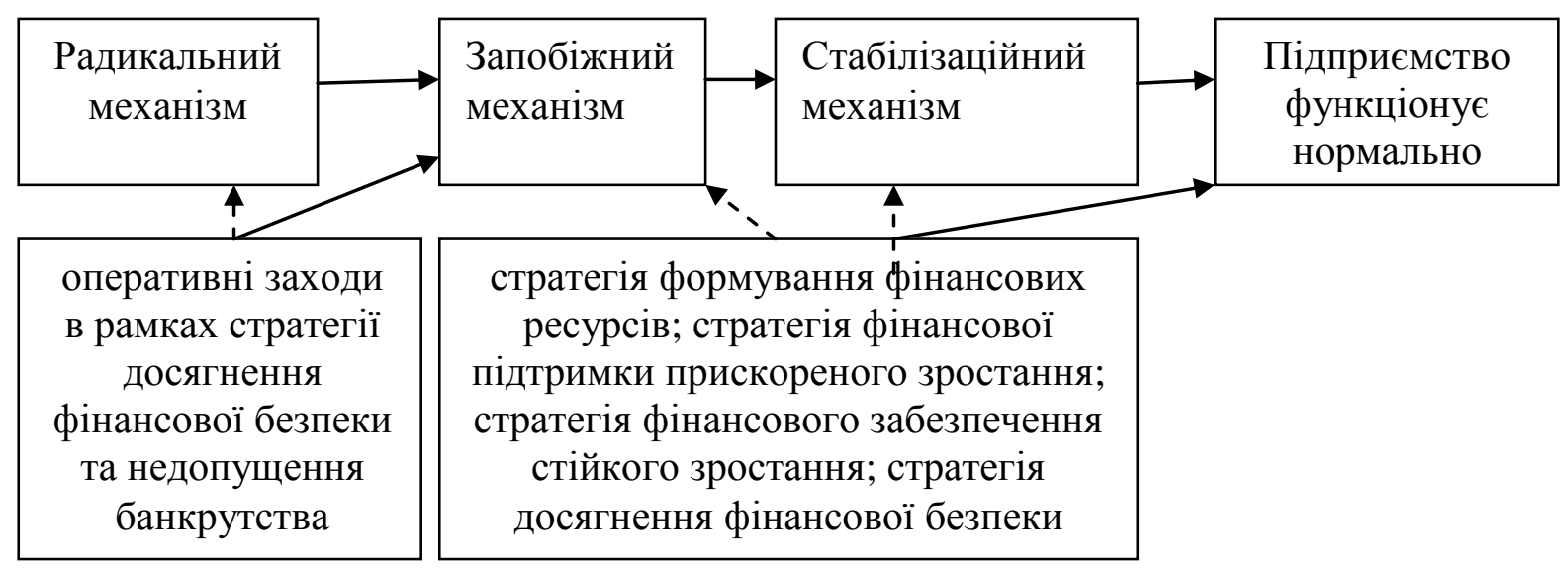

Рис. 1. Блок-схема поетапного виведення підприємства із стану кризи Джерело: Запропоновано автором

За умови ефективного використання радикального механізму підприємство переходить до реалізації запобіжного механізму, у разі неефективного - потрібно переглянути заходи або перейти до процедури ліквідації підприємства. У разі ефективного застосування запобіжного механізму підприємству рекомендовано перехід до стабілізаційного механізму.

Їх застосування дає можливість накопичувати антикризовий потенціал підприємства. Автор виділяє три моделі, які використовуються у фінансовому аналізі для виявлення можливостей накопичення антикризового потенціалу підприємства машинобудування (табл.1). 
Таблиця 1

Основні моделі фінансового аналізу для виявлення можливостей накопичення антикризового потенціалу на підприсмствах машинобудування

\begin{tabular}{|c|c|c|}
\hline Назва моделей & Структурні елементи & Переваги використання \\
\hline $\begin{array}{l}\text { Дескриптивні } \\
\text { (описові) моделі }\end{array}$ & $\begin{array}{l}\text { В основі лежить бухгалтерська звітність: } \\
\text { вертикальний і горизонтальний аналіз } \\
\text { фінансової звітності, побудова системи } \\
\text { звітних балансів, система аналітичних } \\
\text { коефіцієнтів. }\end{array}$ & $\begin{array}{l}\text { Є найбільш часто } \\
\text { використовуваними при } \\
\text { проведенні фінансового } \\
\text { аналізу. }\end{array}$ \\
\hline $\begin{array}{l}\text { Нормативні } \\
\text { моделі }\end{array}$ & $\begin{array}{l}\text { В основі - необхідні розраховані } \\
\text { показники, з якими порівнюють реальні } \\
\text { отримані результати, т. е. існує система } \\
\text { нормативів, яка визначає бажане і } \\
\text { задовільний стан підприємства як мета } \\
\text { діяльності, а аналіз отриманих результатів } \\
\text { дозволяє визначити ступінь досягнення } \\
\text { підприємством цього стану }\end{array}$ & $\begin{array}{l}\text { Використовуються } \\
\text { переважно при } \\
\text { проведенні внутрішнього } \\
\text { фінансового аналізу. }\end{array}$ \\
\hline $\begin{array}{l}\text { Предикативні } \\
\text { моделі } \\
\text { (прогнози) }\end{array}$ & $\begin{array}{l}\text { Моделі ситуаційного аналізу, моделі } \\
\text { динамічного аналізу, критичні моделі }\end{array}$ & $\begin{array}{l}\text { Дозволяють досліджувати } \\
\text { вплив різноманітних } \\
\text { факторів на кінцеві } \\
\text { результати, можливість } \\
\text { отримання беззбиткової } \\
\text { бухгалтерської звітності. }\end{array}$ \\
\hline
\end{tabular}

Обгрунтуємо процедуру вибору механізму антикризового управління на підприємствах машинобудування як основу для накопичення антикризового потенціалу.

Основою вибору механізму антикризового управління $є$ діагностика кризового стану. У процесі ії здійснення є дуже важливим вивчення динаміки основних показників діяльності підприємства за певний період, найчастіше це останні 5-8 років. Це дозволяє виявити терміни, в які підприємство почало погіршувати свої показники, і виявити причини кризи, оскільки відомий приблизний часовий проміжок.

Наступним кроком $є$ оцінювання ефективності наявного механізму антикризового управління підприємства. Ї̈ї в цілому запропоновано оцінювати шляхом розрахунку інтегрального показника ефективності механізму антикризового управління за показниками збалансованої системи. В основу розрахунку інтегрального показника покладена думка, що кількісні показники за 4-групами збалансованої системи (ліквідність, фінансова стійкість, ділова активність та якість менеджменту) впливають на показник антикризового управління підприємства (Іаку $)$, який в свою чергу виступає індикатором ефективності механізму антикризового управління та має статистичний зв'язок з 4-ма складовими-індексами.

3 метою обгрунтування вибору механізму антикризового управління підприємством необхідно визначити межі значень інтегрального показника. 
При визначенні межі значень інтегрального показника було використано визначення прогнозного значення за екстраполяційним методом гармонійних ваг. Він $\epsilon$ методом адаптивного прогнозування, який грунтується на принципі різної інформаційної цінності окремих рівнів ряду динаміки для розрахунку прогнозованого показника. На відміну від методу експоненційного згладжування $\mathrm{P}$. Брауна в методі гармонійних ваг застосовується плинний тренд, а не плинна середня [2-3].

Перед застосуванням методу гармонійних ваг необхідно перевірити початковий ряд динаміки на відсутність різких стрибків і достатність інформаційної бази для прогнозування.

У процесі застосування методу гармонійних ваг формуються фази. До них входять k-рівнів(3 або 5) початкового ряду динаміки. Першу фазу утворюють рівні $\mathrm{y}_{1}, \mathrm{y}_{2}, \ldots, \mathrm{y}_{\mathrm{k}}$, другу $-\mathrm{y}_{2}, \mathrm{y}_{3}, \ldots, \mathrm{y}_{\mathrm{k}+1}$, останню $-\mathrm{y}_{\mathrm{n}-\mathrm{k}+1}, \mathrm{y}_{\mathrm{n}-\mathrm{k}+2}, \ldots, \mathrm{y}_{\mathrm{n}}$. Кількість утворених фаз буде рівна $\mathrm{K}=\mathrm{n}-\mathrm{k}+1$.

Для кожної фази за допомогою методу найменших квадратів знаходимо лінійні рівняння регресії (рівняння плинних трендів):

$$
\hat{y}_{i}(t)=b_{0 i}+b_{1 i} t(i=\overline{1, K} ; \quad t=\overline{i, i+k-1})
$$

На основі знайдених трендів обчислюють середні значення плинного тренду в точках $i=\overline{1, n}$.

Для виконання наступних кроків необхідно перевірити припущення про те, що відхилення від плинного тренду мають випадковий характер і становлять стаціонарний процес. 3 цією метою використано автокореляційну функцію помилок. Якщо відзначене припущення виконується, то наступним кроком реалізації методу гармонійних ваг $\epsilon$ розрахунок середніх приростів. Спочатку розраховують прирости за такою формулою:

$$
W_{t+1}=\bar{y}(t+1)-\bar{y}(t)
$$

Потім знаходять середній приріст за формулою:

$$
\bar{W}=\sum_{t=1}^{n-1} C_{t+1} \cdot W_{t+1}
$$

Величини $C_{t+1}$ - гармонійні коефіцієнти, які розраховують на основі гармонійних ваг. Для визначення гармонійних ваг користуються співвідношенням:

$$
\begin{gathered}
m_{t+1}=\sum_{i=1}^{t} \frac{1}{n-i} \\
m_{t+1}=m_{t}+\frac{1}{n-t}(t=\overline{1, n-1})
\end{gathered}
$$

Найбільш ранній інформації надається вага $m_{2}=1 /(n-1)$.

Гармонійні коефіцієнти визначають за формулою:

$$
C_{t+1}=\frac{m_{t+1}}{n-1}
$$

Точковий прогноз знаходять як суму останнього значення ряду динаміки і середнього приросту: 


$$
y_{t+1}^{\text {прогн }}=\bar{y}(t)+\bar{W}
$$

Інтервал довіри прогнозного значення знаходять користуючись нерівністю Чебишева для випадкової величини $W_{t+1}$ :

$$
P\left\{\left|W_{t+1}-E(W)\right|>a \sigma_{W}\right\}<\frac{1}{a^{2}}
$$

де, а - задане ціле додатне число;

$\sigma_{w}$ - середнє квадратичне відхилення випадкової величини, оцінка якого становить:

$$
\hat{\sigma}_{W}=\sqrt{\sum_{t=1}^{n-1} C_{t+1}\left(W_{t+1}-\bar{W}\right)^{2}}
$$

Довірчі межі для прогнозного значення показника будуть становити:

$$
y_{n+\tau}^{n \text { рогн }}-A(\tau) \hat{\sigma}_{W} \leq y<=y_{n+\tau}^{n p o z H}+A(\tau) \hat{\sigma}_{W}
$$

де, $\tau$ - горизонт прогнозування,

величину $A(\tau)$ розраховують за формулою:

$$
A(\tau)=a \sum_{t=1}^{\tau+1} C_{n-t+1}
$$

3 метою вибору інструментів антикризового управління, адекватних стану кризових явищ на підприємствах, запропоновано інтерпретацію меж інтегрального показника ефективності механізму антикризового управління, зокрема: в межах [0-0,3] рекомендовано використовувати інструменти запобіжного; в межах $(0,3-0,6]$ - інструменти стабілізаційного; в межах $(0,6-1]$ - інструменти радикального механізму антикризового управління.

Застосування математичного апарату та запропонованої етапності виведення підприємства із стану кризи (рис. 1) дають можливість розрахувати прогнозні значення інтегрального показника ефективності механізму антикризового управління.

Для підтвердження об'єктивності запропонованої моделі було обрано підприємства машинобудування, що спеціалізуються на виробництві машин та устаткування. А саме: ПАТ «Запорізький автомобільний завод» (ПАТ «ЗАЗ») та ПАТ «Автомобільна Компанія «Богдан Моторс» (далі ПАТ «АК «Богдан Моторс»), ПАТ «Черкаський автобус» та ПАТ «Завод «Часівоярські автобуси». Вони виробляють майже $63 \%$ загального обсягу автотранспортних засобів в Україні, а тому актуальною для них $є$ фінансова діагностика та оцінювання ймовірності банкрутства.

Результати розрахунків подано у табл. 2 - 6. 
Таблиця 2

\section{Розрахунок прогнозних значень інтегрального показника} ефективності механізму антикризового управління на ПрАТ «БАЗ»

\begin{tabular}{|c|c|c|c|c|c|c|c|c|}
\hline & $\begin{array}{l}\text { значення } \\
\text { інтегрального } \\
\text { показника }(y)\end{array}$ & $\begin{array}{c}\text { Фази плинного } \\
\text { тренду }\end{array}$ & $a_{0}$ & $a_{1}$ & $\overline{y_{t}}$ & $\overline{w_{t+1}}$ & $m_{t+}$ & $C_{t+1}^{n}$ \\
\hline 2005 & 0,49896 & & & & 0,458 & & & \\
\hline 2006 & 0,44507 & & & & 0,504 & 0,046 & 0,143 & 0,020 \\
\hline 2007 & 0,63528 & $2005 ; 2006 ; 2007$ & $-136,19$ & 0,068 & 0,593 & 0,089 & 0,310 & 0,044 \\
\hline 2008 & 0,60387 & $2006 ; 2007 ; 2008$ & $-158,79$ & 0,079 & 0,620 & 0,026 & 0,510 & 0,073 \\
\hline 2009 & 0,64402 & $2007 ; 2008 ; 2009$ & $-8,151$ & 0,004 & 0,663 & 0,043 & 0,760 & 0,109 \\
\hline 2010 & 0,76665 & $2008 ; 2009 ; 2010$ & $-162,84$ & 0,081 & 0,726 & 0,063 & 1,093 & 0,156 \\
\hline 2011 & 0,64511 & $2009 ; 2010 ; 2011$ & $-0,413$ & 0,001 & 0,693 & 0,033 & 1,593 & 0,228 \\
\hline 2012 & 0,68878 & $2010 ; 2011 ; 2012$ & 79,004 & $-0,04$ & 0,661 & $-0,03$ & 2,593 & 0,370 \\
\hline 2013 & 0,66000 & $2011 ; 2012 ; 2013$ & $-14,312$ & 0,007 & 0,672 & 0,011 & 3,593 & 0,513 \\
\hline 2014 & 0,71000 & $2012 ; 2013 ; 2014$ & $-20,673$ & 0,011 & 0,697 & 0,025 & 4,593 & 0,656 \\
\hline 2015 & 0,705 & прогноз & & & & & & \\
\hline 2017 & $\mathbf{0 , 7 2 8}$ & прогноз & & & & & & \\
\hline 2019 & $\mathbf{0 , 7 5 2}$ & прогноз & & & & & & \\
\hline
\end{tabular}

Результати табл. 2 свідчать про тенденцію розгортання кризових явищ на ПрАТ «БАЗ» і підтверджують відповідно до запропонованої інтерпретації меж інтегрального показника необхідність застосування радикального механізму антикризового управління.

Таблиця 3

Розрахунок прогнозних значень інтегрального показника ефективності механізму антикризового управління на ПАТ «ЗАЗ»

\begin{tabular}{|c|c|c|c|c|c|c|c|c|}
\hline & $\begin{array}{l}\text { значення } \\
\text { інтегрального } \\
\text { показника (y) }\end{array}$ & $\begin{array}{c}\text { Фази плинного } \\
\text { тренду }\end{array}$ & $a_{0}$ & $a_{1}$ & $\overline{y_{t}}$ & $\overline{w_{t+1}}$ & $m_{t+1}$ & $C_{t+}^{n}$ \\
\hline 2005 & 0,29307 & & & & 0,304 & & & \\
\hline 2006 & 0,35550 & & & & 0,328 & 0,024 & 0,143 & 0,02 \\
\hline 2007 & 0,35307 & $2005 ; 2006 ; 2007$ & $-59,842$ & 0,030 & 0,386 & 0,058 & 0,310 & 0,04 \\
\hline 2008 & 55233 & 2006; 2007; 2008 & $-197,10$ & 0,098 & 0,540 & 0,154 & 0,510 & 0,07 \\
\hline 2009 & 0,62956 & $2007 ; 2008 ; 2009$ & $-277,08$ & 0,138 & 0,589 & 0,049 & 0,760 & 0,10 \\
\hline 2010 & 0,48390 & $2008 ; 2009 ; 2010$ & 69,297 & $-0,034$ & 0,553 & $-0,036$ & 1,093 & 0,15 \\
\hline 2011 & 0,75345 & $2009 ; 2$ & $-123,88$ & 0,062 & 0,688 & 0,135 & 1,593 & 0,22 \\
\hline 2012 & 0,83723 & $2010 ; 2011 ; 2012$ & $-354,58$ & 0,177 & 0,868 & 0,180 & 2,593 & 0,37 \\
\hline 2013 & 0,85 & $2011 ; 2012 ; 2013$ & $-96,317$ & 0,048 & 0,862 & $-0,006$ & 3,593 & 0,51 \\
\hline 2014 & 0,88 & $2012 ; 2013 ; 2014$ & $-42,194$ & 0,021 & 0,877 & 0,015 & 4,593 & 0,65 \\
\hline 2015 & $\mathbf{0 , 8 7 9}$ & прогноз & & & & & & \\
\hline 2017 & $\mathbf{0 , 8 8 1}$ & прогноз & & & & & & \\
\hline 2019 & $\mathbf{0 , 8 8 3}$ & прогноз & & & & & & \\
\hline
\end{tabular}

Результати табл. Зтакож свідчать про тенденцію розгортання кризових явищ на ПАТ «ЗАЗ» та підтверджують необхідність застосування радикального механізму антикризового управління. 
Таблиця 4

\section{Розрахунок прогнозних значень інтегрального показника ефективності механізму антикризового управління}

на ПАТ «АК «Богдан Моторс»

\begin{tabular}{|c|c|c|c|c|c|c|c|c|}
\hline & $\begin{array}{l}\text { значення } \\
\text { інтегрального } \\
\text { показника (y) }\end{array}$ & $\begin{array}{c}\text { Фази плинного } \\
\text { тренду }\end{array}$ & $a_{0}$ & $a_{1}$ & $\overline{y_{t}}$ & $\overline{w_{t+1}}$ & $m_{t+1}$ & $C_{t+1}^{n}$ \\
\hline 2005 & 0,54859 & & & & 0,567 & & & \\
\hline 2006 & 0,71075 & & & & 0,709 & 0,141 & 0,14 & 0,02 \\
\hline 2007 & 0,76137 & $2005 ; 2006 ; 2007$ & $-212,74$ & 0,106 & 0,727 & 0,018 & 0,310 & 0,04 \\
\hline 2008 & 0,61481 & $2006 ; 2007 ; 2008$ & 96,96 & $-0,048$ & 0,680 & $-0,046$ & 0,510 & 0,07 \\
\hline 2009 & 0,81104 & $2007 ; 2008 ; 2009$ & $-49,13$ & 0,025 & 0,764 & 0,084 & 0,760 & 0,11 \\
\hline 2010 & 0,71389 & $2008 ; 2009 ; 2010$ & $-98,81$ & 0,050 & 0,695 & $-0,069$ & 1,093 & 0,16 \\
\hline 2011 & 0,52850 & $2009 ; 2010 ; 2011$ & 284,63 & $-0,141$ & 0,611 & $-0,085$ & 1,593 & 0,23 \\
\hline 2012 & 0,79146 & $2010 ; 2011 ; 2012$ & $-77,31$ & 0,039 & 0,717 & 0,106 & 2,593 & 0,37 \\
\hline 2013 & 0,58000 & $2011 ; 2012 ; 2013$ & $-51,17$ & 0,026 & 0,659 & $-0,058$ & 3,593 & 0,51 \\
\hline 2014 & 0,57000 & $2012 ; 2013 ; 2014$ & 223,55 & $-0,111$ & 0,536 & $-0,123$ & 4,593 & 0,66 \\
\hline 2015 & 0,539 & прогноз & & & & & & \\
\hline 2017 & 0,541 & прогноз & & & & & & \\
\hline 2019 & 0,543 & прогноз & & & & & & \\
\hline
\end{tabular}

Результати табл. 4 свідчать про тенденцію розгортання кризових явищ на ПАТ «АК «Богдан Моторс». Вони підтверджують необхідність застосування стабілізаційного механізму антикризового управління.

Таблиця 5

Розрахунок прогнозних значень інтегрального показника ефективності механізму антикризового управління ПАТ «Завод «Часівоярські автобуси»

\begin{tabular}{|c|c|c|c|c|c|c|c|c|}
\hline & $\begin{array}{l}\text { значення } \\
\text { інтегрального } \\
\text { показника (y) }\end{array}$ & $\begin{array}{c}\text { Фази плинного } \\
\text { тренду }\end{array}$ & $a_{0}$ & $a_{1}$ & $\overline{y_{t}}$ & $\overline{w_{t+1}}$ & $m_{t+1}$ & $C_{t+1}^{n}$ \\
\hline \multicolumn{9}{|c|}{ ПАТ « Завод «Часівоярські автобуси» } \\
\hline 2005 & 0,75902 & & & & 0,692 & & & \\
\hline 2006 & 0,43303 & & & & 0,502 & $-0,190$ & 0,143 & 0,02 \\
\hline 2007 & 0,51031 & $2005 ; 2006 ; 2007$ & 250,02 & $-0,124$ & 0,490 & $-0,012$ & 0,310 & 0,04 \\
\hline 2008 & 0,56469 & $2006 ; 2007 ; 2008$ & $-131,62$ & 0,066 & 0,565 & 0,075 & 0,510 & 0,07 \\
\hline 2009 & 0,52923 & $2007 ; 2008 ; 2009$ & $-18,462$ & 0,009 & 0,497 & $-0,069$ & 0,760 & 0,10 \\
\hline 2010 & 0,32341 & $2008 ; 2009 ; 2010$ & 242,84 & $-0,121$ & 0,365 & $-0,132$ & 1,093 & 0,15 \\
\hline 2011 & 0,44925 & $2009 ; 2010 ; 2011$ & 80,814 & $-0,040$ & 0,435 & 0,070 & 1,593 & 0,22 \\
\hline 2012 & 0,65709 & $2010 ; 2011 ; 2012$ & $-335,04$ & 0,167 & 0,643 & 0,208 & 2,593 & 0,37 \\
\hline 2013 & 0,64000 & $2011 ; 2012 ; 2013$ & $-191,30$ & 0,095 & 0,677 & 0,034 & 3,593 & 0,51 \\
\hline 2014 & 0,67000 & $2012 ; 2013 ; 2014$ & $-12,336$ & 0,006 & 0,662 & $-0,015$ & 4,593 & 0,65 \\
\hline 2015 & 0,664 & прогноз & & & & & & \\
\hline 2017 & 0,743 & прогноз & & & & & & \\
\hline 2019 & $\mathbf{0 , 8 2 1}$ & прогноз & & & & & & \\
\hline
\end{tabular}

Результати табл. 5 свідчать про тенденцію розгортання кризових явищ на ПАТ «Завод «Часівоярські автобуси» та підтверджують необхідність 
застосування радикального механізму антикризового управління відповідно до запропонованої інтерпретації меж інтегрального показника.

Таблиия 6

Розрахунок прогнозних значень інтегрального показника ефективності механізму антикризового управління ПАТ «Черкаський автобус»

\begin{tabular}{|c|c|c|c|c|c|c|c|c|}
\hline & $\begin{array}{l}\text { значення } \\
\text { інтегрального } \\
\text { показника (y) }\end{array}$ & $\begin{array}{c}\text { Фази плинного } \\
\text { тренду }\end{array}$ & $a_{0}$ & $a_{1}$ & $\overline{y_{t}}$ & $\overline{w_{t+1}}$ & $m_{t+1}$ & $C_{t+1}^{n}$ \\
\hline \multicolumn{9}{|c|}{ ПАТ «Черкаський автобус» } \\
\hline 2005 & 0,65691 & & & & 0,617 & & & \\
\hline 2006 & 0,41862 & & & & 0,453 & $-0,164$ & 0,143 & 0,02 \\
\hline 2007 & 0,42108 & $2005 ; 2006 ; 2007$ & 237,03 & $-0,118$ & 0,415 & $-0,038$ & 0,310 & 0,04 \\
\hline 2008 & 0,49602 & $2006 ; 2007 ; 2008$ & $-77,220$ & 0,039 & 0,506 & 0,091 & 0,510 & 0,07 \\
\hline 2009 & 0,59059 & $2007 ; 2008 ; 2009$ & $-169,68$ & 0,085 & 0,567 & 0,061 & 0,760 & 0,10 \\
\hline 2010 & 0,47519 & $2008 ; 2009 ; 2010$ & 21,438 & $-0,010$ & 0,463 & $-0,104$ & 1,093 & 0,15 \\
\hline 2011 & 0,34795 & $2009 ; 2010 ; 2011$ & 244,32 & $-0,121$ & 0,416 & $-0,047$ & 1,593 & 0,22 \\
\hline 2012 & 0,62576 & $2010 ; 2011 ; 2012$ & $-150,90$ & 0,075 & 0,558 & 0,142 & 2,593 & 0,37 \\
\hline 2013 & 0,57000 & $2011 ; 2012 ; 2013$ & $-222,87$ & 0,111 & 0,626 & 0,067 & 3,593 & 0,51 \\
\hline 2014 & 0,71000 & $2012 ; 2013 ; 2014$ & $-84,155$ & 0,042 & 0,677 & 0,052 & 4,593 & 0,65 \\
\hline 2015 & 0,679 & прогноз & & & & & & \\
\hline 2017 & 0,682 & прогноз & & & & & & \\
\hline 2019 & 0,684 & прогноз & & & & & & \\
\hline
\end{tabular}

Джерело: Складено автором на основі розрахунків

Результати табл. 6 свідчать про тенденцію розгортання кризових явищ на ПАТ «Черкаський автобус» та підтверджують необхідність застосування стабілізаційного механізму антикризового управління.

В межах кожного механізму доцільно застосовувати відповідні інструменти, використання яких стане основою накопичення антикризового потенціалу обраної групи підприємств машинобудування.

В межах запобіжного механізму рекомендовано використовувати такі інструменти:підтримка інвестування у виробничі процеси; мотивація акціонерів; обгрунтування здійсненності інвестиційних проектів; підтримання платоспроможності за рахунок контролю за розрахунками покупців; оптимізація витрат на виробництво; перегляд системи фінансового управління; формування резервних фондів накопичення фінансування необхідного приросту оборотних та необоротних активів для забезпечення високих темпів росту обсягів виробництва; контроль динаміки короткострокових зобов'язань; нарощення власних засобів за рахунок емісії акцій чи залучення інвестицій.

При реалізації стабілізаційного механізму антикризового управління доцільними $є$ наступні: збалансування способів залучення фінансових ресурсів для мінімізації ризиків і забезпечення розширення обсягів реалізації; підбір інвестиційних проектів за окупністю, що відповідає темпам росту ринку; управління дебіторською й кредиторською заборгованістю; обмеження росту обсягів короткострокових пасивів порівняно із 
довгостроковими; підвищення результативності поточної виробничої діяльності; збільшення частки власного капіталу в оборотних коштах; підтримання платоспроможності за рахунок контролю за розрахунками покупців; оптимізація витрат на виробництво; перегляд системи фінансового управління; формування резервних фондів накопичення; вибір гнучких методів оновлення виробничих фондів; скорочення виплат, які здійснюються 3 прибутку; оптимізація структури активів, досягнення високої інтенсивності їх використання; диверсифікація постачальників; підвищення інтенсивності використання ресурсів; оптимізація цінової політики; реструктуризація портфелю короткострокових кредитів із переведенням частини їх довгострокові.

У процесі застосування радикального механізму антикризового управління рекомендовано використання таких інструментів: економія інвестиційних ресурсів шляхом вибору перспективних бізнес-проектів та консервація капіталомістких; страхування фінансових ризиків покриття дефіциту власного капіталу; досягнення ритмічності грошових потоків; обмеження росту поточних зобов'язань; нарощення частки швидко ліквідних активів; економія, скорочення та жорсткий контроль поточних витрат; утримання результативності використання капіталу; скорочення виплат 3 прибутку; вживання заходів 3 стягнення дебіторської заборгованості; скорочення об'єму фінансових операцій на найбільш ризикованих напрямах діяльності; покриття збитків, недопущення їх накопичення, реалізація невживаних активів; пролонгація кредитних зобов'язань; ліквідація портфеля короткострокових фінансових вкладень; упровадження антикризової санації та реструктуризації.

Крім того, запропонована процедура дозволяє здійснювати прогноз ефективності застосування рекомендованого механізму антикризового управління і виявити накопичений антикризовий потенціал. Для обраних підприємств прогнозні значення інтегрального показника підтвердили ефективність застосування запропонованих механізмів антикризового управління. Лише для ПАТ «ЗАЗ» та ПАТ «Завод «Часівоярські автобуси» прогноз показав доцільність застосування оперативних антикризових дії. Для ПАТ «АК «Богдан Моторс» прогнозні значення є мінімальними, проте результати свідчать про наявність кризових явищ та неспроможність самостійно подолати їх наслідки. Також результати розрахунків дають можливість зробити висновок, що при ігноруванні наданих рекомендацій функціонування підприємств буде порушено в негативну сторону.

Графічна інтерпретація результатів подана на рис. 2. 


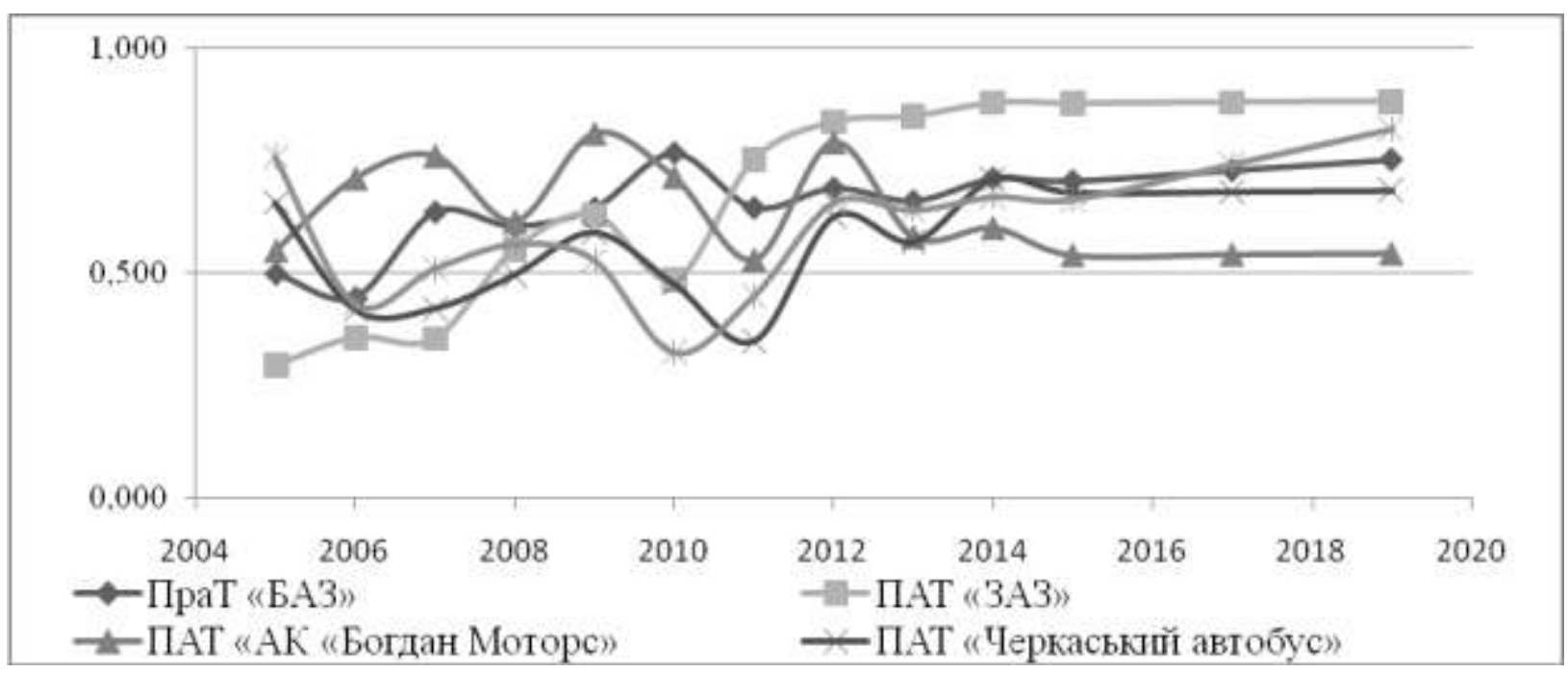

Рис. 2. Динаміка інтегрального показника антикризового управління на підприємствах машинобудування в 2005-2015pp.

Джерело: Побудовано автором на основі розрахунків

Результати рис. 2. свідчать про те, що застосування інтегрального показника ефективності механізму антикризового управління дає можливість збільшити об'єктивність при оцінці ймовірності банкрутства підприємств машинобудування за рахунок врахування нефінасових показників, що безпосередньо впливають на фінансовий стан підприємства $\mathrm{i}$ дають можливість накопичувати антикризовий потенціал.

Таким чином, на основі прогнозних значень інтегрального показника ефективності механізму антикризового управління для ПАТ «ЗАЗ» та ПрАТ «БАЗ», ПАТ «Завод «Часівоярські автобуси» та ПАТ «Черкаський автобус» рекомендовано застосувати радикальний механізм антикризового управління; для ПАТ «Богдан Моторс» - стабілізаційний механізм антикризового управління.

Висновки. Наукова новизна дослідження полягає в обгрунтуванні процедури вибору механізму антикризового управління на підприємствах машинобудування, що на відміну від наявних, базується на врахуванні значень інтегрального показника оцінювання ефективності наявного механізму антикризового управління та дозволяє на основі співвідношення антикризових заходів 3 фазами розгортання кризових явищ надавати рекомендації щодо вибору механізму антикризового управління, який дозволить накопичувати антикризовий потенціал.

Результати дослідження мають теоретичне та практичне значення, оскільки можуть бути використані для недопущення, попередження та ліквідації наслідків кризи на підприємстві в процесі реалізації механізму антикризового управління в рамках стратегії розвитку підприємства.

У ході досліджень було визначено, що динаміка в цілому підтверджує реальний стан підприємств та корелюється 3 результатами методик оцінки ймовірності банкрутства, що $є$ найбільш прийнятними для вітчизняних підприємств. 
Розраховані значення свідчать про наявність кризових явищ на підприємствах протягом аналізованого періоду та необхідність застосування запропонованої процедури вибору механізму антикризового управління залежно від індивідуальних значень інтегрального показника ефективності механізму антикризового управління.

Зважаючи на той факт, що антикризові заходи не є універсальними та уніфікованими для різних типів криз з різною глибиною та формою прояву розгортання на відповідній стадії, в перспективних подальших наукових розробках даний напрям потребує уточнення науково-методичних підходів до організації процесу антикризового управління на підприємствах машинобудування.

\section{Література:}

1. Бєлозерцев О. В. Оцінка антикризового потенціалу вугледобувних підприємств: дис. кандидата екон. наук: 08.06.01 / О. В. Бєлозерцев. - Алчевськ, 2003. - 209 с.

2. Благуш П. Факторный анализ с обобщениями / П. Благуш - М. : Финансы и статистика, 1989. - 248 с.

3. Леоненко М. М. Теоретико-ймовірнісні та статистичні методи в економетриці та фінансовій математиці / М. М. Леоненко, Ю. С. Мішура, В. М. Пархоменко, М. Й.Ядренко. - К : Інформтехніка, 2005. - 380 с.

4. Погребняк А.Ю. К вопросу о накоплению антикризисного потенциала на промышленных предприятих Украины / А. Ю. Погребняк // International scientific journal «PROGRESS». - Международная академия социально-єкономических наук. Тбилиси : Международное издательство «Прогресс» - 2013. - №1-2. - С. 150-156.

5. Погребняк А.Ю. Проблеми вибору методики оцінки ефективності механізму антикризового управління на промисловому підприємстві / А. Ю. Погребняк // Економічний вісник НТУУ «КПІ». - 2013. - № 10. - С.224-230

6. Рекова Н.Ю. Антикризові резерви формування фінансового потенціалу інституційної інфраструктури / Н. Ю. Рекова, Н. А. Ясинська // Молодий вчений : науковий журнал. - 2015. - Вип. 12 (28). - С. 82-89.

7. Сейсебаєва Н.Г. Проблеми відновлення виробничого потенціалу підприємств машинобудування / Н. Г. Сейсебаєва// Формування ринкових відносин в Україні : зб. наук. праць / Наук. ред. І. Г. Манцуров. - К., 2015. - Вип. 6 (169). — С. 130-133. 